\author{
Claude Mutafian \\ UNIVERSITÉ PARIS XIII
}

\title{
ORMIAŃSKA DIASPORA \\ OD STAROŻYTNOŚCI DO NOWOCZESNOŚCI
}

Pierwsza ormiańska książka została wydrukowana w Wenecji w roku 1511 lub 1512, podczas gdy pierwsza publikacja książkowa w Wielkiej Armenii ukazała się w Eczmiadzynie 260 lat później, w 1772 roku, po ponad 640 tytułach już wydrukowanych poza ziemiami ormiańskimi (ilustr. A). Jeśli chodzi o prasę, to pierwsze ormiańskie czasopismo zostało wydane w Madrasie w Indiach w 1794 roku. Odkąd Armenia została podzielona między dwa imperia, jej stolicami kulturalnymi były Konstantynopol dla Turcji osmańskiej i Tyflis (dziś: Tbilisi) dla Armenii rosyjskiej - oba miasta położone również poza Wielką Armenią.

Te fakty dają wyobrażenie o znaczeniu zjawiska diaspory w historii i kulturze ormiańskiej. Istniały różne kategorie diaspor: bliskie i odległe, przymusowe i dobrowolne, skoncentrowane i rozproszone, kulturowe i ekonomiczno-polityczne.

\section{Rzym i Bizancjum (do IX wieku)}

Chociaż znamy niektóre ormiańskie osady w państwach hellenistycznych po podboju przez Aleksandra Macedońskiego, pierwsza prawdziwa diaspora powstała później, jako konsekwencja rzymskiej ekspansji na Wschodzie po klęsce Tygranesa Wielkiego. Potężne Cesarstwo Rzymskie miało wielką siłę przyciągania: w 66 roku Tyrydates, założyciel nowej dynastii królewskiej w Armenii, musiał udać się do Rzymu, aby otrzymać koronę od cesarza Nerona. Migracja Ormian do cesarstwa wzrosła w IV wieku, kiedy chrześcijaństwo zostało ogłoszone religią państwową, kilka dekad po tym, jak Armenia i Rzym stały się centrum chrześcijańskiego świata. Wielu Ormian było znanych w cesarstwie, co wynika ze źródeł epigraficznych lub literackich, autorów takich jak Quirillus, Aedesius 
lub słynny retor Prohaeresios z IV wieku. Liczne echa kultury Armenii można też odnaleźć w literaturze łacińskiej.

W 428 roku Królestwo Armenii zniknęło na cztery i pół stulecia, a jego terytorium zostało podzielone między Rzym i Persję Sasanidów, później zastąpioną przez kalifat arabski. W takich okolicznościach rodziły się ważne kolonie ormiańskie we wschodniej części Cesarstwa Rzymskiego, które po upadku Rzymu stało się Cesarstwem Bizantyjskim. Chociaż Kościół ormiański, po odrzuceniu dogmatów ogłoszonych na soborze chalcedońskim, został uznany przez Rzym i Konstantynopol za „schizmatycki”, Ormianie kontynuowali migrację na Zachód, głównie ze strachu przed Wschodem - najpierw zoroastriańskim, a potem muzułmańskim. Bizancjum praktykowało klasyczną „politykę kolonialną”, skutecznie naśladowaną wiele wieków później przez Francję i Wielką Brytanię, które zwykły umieszczać swoje mniejszości, Arabów lub Afrykanów, w niebezpiecznej linii frontu. Doceniając umiejętności wojskowe swoich ormiańskich poddanych, Bizancjum przesiedliło ich, by ochronić swoje granice przed Bułgarami na zachodzie oraz Persami i Arabami - na wschodzie.

W konsekwencji ta rozproszona diaspora ormiańska, częściowo zasymilowana, zakończyła się zdobyciem ważnych pozycji w cesarstwie. Najlepszym tego przykładem jest cesarska dynastia, zwana macedońską, która w rzeczywistości wywodziła się z Ormian osiadłych w Macedonii.

\section{Jerozolima i Włochy (do XI wieku)}

W tym samym okresie pojawiły się dwie główne diaspory kulturowe w następstwie chrystianizacji Cesarstwa Rzymskiego. Pierwsza z nich znajdowała się w Jerozolimie i była złożona głównie z osób duchownych, co pokazuje słynna „Lista Anastazjusza” 70 ormiańskich klasztorów w Świętym Mieście w VII wieku, a także odkryta tam jeszcze bardziej starożytna ormiańska mozaika (ilustr. B). Diaspora ta przetrwała do czasów współczesnych. Siedziba patriarchatu ormiańskiego znajduje się w dzielnicy ormiańskiej, która jest oficjalnie jedną z czterech części Starego Miasta.

Natomiast druga diaspora była rozproszona we Włoszech. Oprócz Rzymu, gdzie w VII wieku udokumentowano istnienie klasztoru ormiańskiego, wielu ormiańskich urzędników żyło w tym samym czasie w innych miastach, takich jak Rawenna, a święci ormiańscy byli czczeni w Mantui i Lukce. Najważniejsza diaspora znajdowała się na południu Włoch i na Sycylii, która dostała się pod panowanie Bizancjum i gdzie cesarze zarządzili wymuszone migracje ludności. Wielu Ormian w Apulii i Kalabrii zajmowało ważne stanowiska w administracji lub armii. Święty Grzegorz Oświeciciel był czczony w miastach Nardo i Neapol, a od X wieku znamy ormiańskie kościoły w Bari, Materze i Forenzy (ilustr. E). 


\section{Armenia Cylicyjska (XII-XIV wiek)}

W 1045 roku Bizancjum anektowało ostatnie królestwo Armenii w wielkiej Armenii, a niespełna 20 lat później podbój Turków spowodował kolejną migrację wielu rodzin. Ormianie udawali się zasadniczo tam, gdzie istniały już osady ich rodaków. Tak było w Cylicji, strategicznym kraju na północno-wschodnim krańcu Morza Śródziemnego, na ruchliwym pograniczu bizantyńsko-arabskim (ilustr. C). Zgodnie z zasadami swej polityki „kolonialnej” cesarstwo na przestrzeni wieków przesiedliło na ten obszar wielu ze swych ormiańskich poddanych. Konstelacja tutejszych księstw stanowiła atrakcję dla Ormian poszukujących nowego domu. W konsekwencji Cylicja, wraz z łańcuchami górskimi Taurus i Amanus, powoli połączyła się ze swoim wschodnim sąsiadem, Eufratensis, tworząc coś w rodzaju „nowej Armenii”.

Niemniej jednak przyszłość pokazała, że nie miała to być diaspora taka jak inne, ponieważ ta migracja daleka była od klasycznych typów takich przemieszczeń. Tworzyła bardzo szczególny rodzaj „migracji państwowej”. Jej celem nie było jedynie osiedlenie się w obcym kraju, ale stworzenie nowego państwa ormiańskiego. Jednym słowem, była to próba przeniesienia państwa, a nie zwykłe przeniesienie ludności. Aby osiągnąć taki cel, potrzebna była bardzo specyficzna umiejętność dyplomatyczna.

Cylicja, położona na drodze z Konstantynopola do Jerozolimy, stała się miejscem, które musieli przekroczyć krzyżowcy, dążąc do Ziemi Świętej. Korzystając z tej nowej sytuacji, dynastia Rubenidów uprawiała grę dyplomatyczną przez cały XII wiek w formie mobilnych sojuszów z Grekami, Arabami, Turkami i „Frankami”. Cel został osiągnięty w styczniu 1198 roku, kiedy książę Leon został koronowany w Tarsie na króla Cylicji i wkrótce uznany przez mocarstwa zachodnie, papiestwo, Bizancjum i świat muzułmański (ilustr. C). To „królestwo Armenii poza Armenią” wybijało monety z napisem „Król Armenii”, a nawet „Król całej Armenii” (ilustr. D), która to tytulatura była szeroko stosowana w oficjalnych dokumentach, odzwierciedlając fakt, że chociaż nie kryła się za nią żadna konkretna treść, Ormianie rozproszeni po całym świecie uznali to królestwo za swoje. Dopiero po jego upadku, w 1375 roku, Ormianie w Cylicji mogą być uważani za diasporę.

\section{Utrwalenie włoskiej diaspory (XIII-XVIII wiek)}

Ostatnie królestwo Armenii wzmocniło ruch diasporowy. Mając dostęp - po raz pierwszy w swych dziejach - do wybrzeża Morza Śródziemnego, Ormianie kultywowali bliskie stosunki z Europą, a zwłaszcza z potęgami handlowymi, z których najważniejszymi były miasta włoskie, głównie Wenecja i Genua. W pierwszej kolejności diaspora włoska nabrała nowego impetu podczas zmierzchu królestwa, a XIV wiek pozostaje złotym wiekiem migracji ormiańskiej we Włoszech. Praktycznie każde ważne miasto włoskie, porty i miasta wewnętrz- 
ne, miały swoją społeczność ormiańską z własnym domus (miejscem spotkań) i kościołem, a często także ze skryptorium (ilustr. E). Najstarsze ormiańskie manuskrypty we Włoszech zostały skopiowane już w XIII wieku, najpierw w Rzymie (1239), potem w Rimini (1254) i w wielu innych miastach. W tym samym stuleciu ciekawa inskrypcja „S. Miniatus rex Erminie” na mozaice absydy kościoła San Miniato al Monte we Florencji pozostaje wciąż nierozszyfrowaną tajemnicą (ilustr. F). Odniesienia do Ormian były powszechne w średniowiecznej literaturze włoskiej. Przytoczmy XV-wieczne teksty Leonarda da Vinci i jego „strony ormiańskie” w Codex Atlanticus. Jak już powiedzieliśmy, Wenecja była miejscem narodzin ormiańskiego druku na początku XVI wieku. W następnym stuleciu powstał port w Livorno jako centrum ormiańskiego handlu, a w 1717 roku założony został klasztor mechitarystów na weneckiej wyspie San Lazzaro (ilustr. G). To wszystko potwierdza uprzywilejowaną rolę włoskiej diaspory.

\section{Francuska diaspora (od XIII wieku)}

Krzyżowcy nazywani byli Frankami ze względu na kraj pochodzenia większości z nich. W konsekwencji język i kultura francuska przenikały cylicyjską Armenię. Pierwsze dzieło napisane przez Ormianina w języku zachodnim powstało po francusku. Jego autorem był książę Hetum około 1300 roku, a małżeństwa francusko-ormiańskie były dość powszechne wśród szlachty. Pierwszymi królowymi Jerozolimy były ormiańskie księżniczki (ilustr. H), a ostatnimi królami Armenii cylicyjskiej byli rycerze francuscy (ilustr. I).

Relacje te prowokowały pewną migrację do Francji i narodziny doskonałego przykładu diaspory kulturowej, nieporównywalnej wielkością z włoską, ale bardziej aktywnej. W XVII wieku ormiańskie książki drukowano w Paryżu i Marsylii, a pierwszą kawiarnię w Paryżu otworzył Ormianin. Orientalizm stał się modny, był popierany przez osobistości takie jak Richelieu czy Colber, a także przez wielu pisarzy i artystów. Na początku XIX wieku Napoleon stworzył katedrę ormiańską w École des langues orientales, a francuska armenologia stała się jedną z wiodących na świecie. Diaspora ormiańska we Francji zachowała swój intelektualny charakter do czasu ludobójstwa w 1915 roku. Późniejszy napływ uchodźców z Turcji całkowicie zmienił jej liczebność i jest to obecnie najważniejsza diaspora w Europie.

\section{Diaspory Europy bałkańskiej (od V wieku)}

Bałkańska Europa, na południe od Dunaju, w niedługim czasie została zamieszkana przez dużą ormiańską diasporę w wyniku dwóch wymiarów polityki bizantyńskiej. Pierwszy, wspomniany wcześniej, to tradycyjna polityka kolonialna wobec bułgarskiego zagrożenia. Drugi powód związany był z rozwojem tzw. sekt religijnych, głównie paulicjan i tondrakianów, które kwitły szczególnie w mniejszych dzielnicach Azji zamieszkałych przez Ormian. Aby powstrzymać ich eks- 
pansję, cesarz zlecił masowe transfery Ormian do odległych europejskich prowincji. Ślad tego ruchu można znaleźć w nazwie bułgarskiego miasta Pavlikeni. Taka polityka mogła mieć czasem nieoczekiwane konsekwencje. Ormiańscy deportowani skłonni byli sprzymierzyć się z bułgarskim wrogiem przeciwko władzy, która zmusiła ich do emigracji. Najlepszym tego przykładem jest Samuel, bułgarski car pochodzenia ormiańskiego, który walczył z cesarzem Bazylim II.

Zachowało się wiele świadectw na temat tej ormiańskiej diaspory (ilustr. J). Jednym z nich jest znakomity Ewangeliarz Adrianopolski, skopiowany i zilustrowany w tym trackim mieście (potem tureckie Edirne - ilustr. K). Pod koniec następnego stulecia, podczas trzeciej krucjaty, armia niemiecka przeszła przez Filipopolis (obecny bułgarski Płowdiw), gdzie została przyjęta w ważnej ormiańskiej dzielnicy miasta. Ormiańska diaspora w Europie bałkańskiej rozwijała się nadal pod rządami tureckimi.

\section{Diaspory Europy krymsko-karpackiej (XIV wiek)}

Ormiańska diaspora w Europie karpackiej jest dużo nowsza niż bałkańska, z powodu braku silnych związków tych obszarów z Bizancjum. Jej narodziny można ustalić na XIV wiek (ilustr. L), głównie w okolicach Lwowa (ilustr. Ł), na Wołyniu, Podolu i w Mołdawii.

Istnieje legenda o jej szczególnym pochodzeniu. Ze względu na zdobycie miasta Ani przez Turków w 1064 roku, a później przez Mongołów w 1236 roku, a także na kolejne trzęsienia ziemi, ludność dawnej stolicy Armenii przekroczyła masowo Morze Czarne i znalazła schronienie na tych obszarach. Ta opowieść, która pozwala rumuńskim Ormianom uważać się za potomków słynnego Ani, została po raz pierwszy rozpowszechniona w XVIII wieku, ale nie ma nawet jednego współczesnego źródła pozwalającego na taką interpretację. Być może niektórzy z Ormian poszli tym szlakiem, ale prawdziwy obraz jest zupełnie inny.

Na północ od Dunaju diaspora ta jest raczej związana z podbojem Mongołów i włoską diasporą. Pierwszy wariant jest konsekwencją dobrze znanych przyjaznych stosunków, które Ormianie mieli od dłuższego czasu z Mongołami. Ormiańscy kupcy osiedlili się na brzegu Wołgi, w Saraju, stolicy Złotej Ordy. Później przenieśli się na zachód albo na Krym, albo - idąc doliną Dniepru - do Kijowa, a następnie na Wołyń i Ruś (ilustr. M). Jeśli chodzi o drugi wariant, opiera się on na głębokich stosunkach handlowych między cylicyjską Armenią a republiką Genui. Genueńczycy dostali od Złotej Ordy zezwolenie na osiedlenie się na południowym brzegu Krymu, a podczas agonii cylicyjskiej Armenii zaoferowali Ormianom schronienie na tym wybrzeżu. Krym wkrótce stał się jedną z najważniejszych ormiańskich diaspor, a w portowym mieście Kaffa (dzisiejsza Feodosia) ludność ormiańska stanowiła bezwzględną większość w połowie XV wieku. Znaczenie Krymu ormiańskiego było w dużej mierze kulturalne, z siecią kościołów, inskrypcjami, słynnymi manuskryptami zawierajacymi wspaniałe miniatury 
(ilustr. N). Część Ormian krymskich przeprowadziła się na ziemie dzisiejszej Rumunii przez Akerman i dolinę Dniestru, ale wydaje się, że większość wyjechała najpierw na północ na Wołyń, Ruś i Podole, a potem na południe na Bukowinę i do Mołdawii (ilustr. N).

Diaspora karpacka była szczególnie aktywna, w różnych swych komponentach. W średniowiecznej Polsce Lwów mieścił siedzibę arcybiskupstwa ormiańskiego i stał się w 1616 roku czwartym centrum ormiańskiego druku po Wenecji, Konstantynopolu i Rzymie. Inne ważne ośrodki to Kamieniec Podolski, Łuck, Kuty, Zamość. Na Bukowinie i w Mołdawii pierwsze wspólnoty powstały w dwóch sukcesywnych stolicach: Suczawie i Jassach, a także w Czerniowcach, Botoszanach, Romanie, Fokszanach. Należy dodać jeszcze Dobrudżę z Gałaczem i Konstancą oraz Besarabię z Akermanem (ilustr. O).

Owe ormiańskie diaspory miały mieć rozbieżne trajektorie według państw, do których należały. W północnej diasporze katolickiej Polski nastąpiła unia Kościoła ormiańskiego z katolickim, co doprowadziło do rozłamu z diasporą południową. Mołdawia formalnie była wasalem Wysokiej Porty, a mimo pewnych okresów prześladowań greckiemu Kościołowi prawosławnemu nigdy nie udało się nawrócić Ormian, którzy pozostali wierni swojemu narodowemu wyznaniu wiary. W konsekwencji życie Ormian w Mołdawii i na Wołoszczyźnie było szczególnie spektakularne do drugiej wojny światowej, jak można zauważyć, dzięki witalności tamtejszej ormiańskiej prasy (ilustr. P).

Pod koniec XVII wieku na zachód od Karpat pojawiła się nowa ormiańska diaspora. $Z$ różnych powodów niektórzy mołdawscy Ormianie przemierzali góry i osiedlali się w węgierskim Siedmiogrodzie pod władzą Habsburgów. Około 1700 roku założyli miasto pod nazwą Armenopolis lub Armenierstadt (obecnie Gherla), jedyny taki przykład w Europie (ilustr. Q). Podobnie jak w Polsce, presja władz katolickich doprowadziła siedmiogrodzkich Ormian do poddania się Rzymowi. Pomimo aneksji Siedmiogrodu przez Rumunię w 1918 roku nadal mówią oni po węgiersku. Podobnie jak oni, praktycznie wszyscy Ormianie w Karpatach zatracili swój ojczysty język, ale widzimy wśród nich pewnego rodzaju kulturowe przebudzenie.

\section{Dwie wymuszone diaspory kulturowe (XVII-XVIII wiek)}

Na początku XVII wieku Armenia została podzielona między Imperium Osmańskie i Persję, nieustannie toczące ze sobą wojny. Perski szach Abbas I postanowił pozostawić nacierającemu wrogowi opuszczoną ziemię. Właśnie przeniósł swoją stolicę do Isfahanu i chciał skorzystać z umiejętności ormiańskich rzemieślników. $\mathrm{Z}$ tych dwóch powodów siłą przemieścił tysiące Ormian $\mathrm{z}$ doliny Araksu, w tym z miasta Dżulfa, na obrzeża Isfahanu, gdzie przyznał im różne przywileje.

W 1605 roku założyli oni dzielnicę Nowa Dżulfa, która stała się ważnym ośrodkiem kultury ormiańskiej - ze skryptorium powstałym już w 1607 roku 
i drukarnią w 1638 roku. W ciągu kilku dziesięcioleci Nowa Dżulfa stała się ważnym elementem handlu Wschód-Zachód. Tamtejsi Ormianie zorganizowali ogromną sieć komercyjnych ośrodków, od Kadyksu i Petersburga na zachodzie, po Filipiny i Indonezję na wschodzie (ilustr. R). Jej „klejnotem” były Indie, gdzie powstała diaspora kulturowa. Madras był szczególnie znany, zwłaszcza ze względu na zasłony (ilustr. S) i miejsce narodzin ormiańskiej prasy w 1794 roku.

Inny przykład wymuszonej diaspory pochodzi z końca XVIII wieku. Aby wzmocnić południową granicę Rosji przed Persją i Imperium Osmańskim, cesarzowa Katarzyna przeniosła Ormian z niedawno podbitego Krymu nad ujście rzeki Don, gdzie założyli miasto Nowy Nachiczewan. Stało się ono rdzeniem ormiańskiej diaspory na Północnym Kaukazie, a obecnie jest dzielnicą Rostowa nad Donem.

\section{Diaspory i masakry (XIX-XX wiek)}

W XIX wieku europejska diaspora była już osłabiona przez asymilację. Terytorium ormiańskie znajdowałao się pod władzą Rosji lub Imperium Osmańskiego. Masakry tureckie rozpoczęły się pod koniec stulecia, a ich kulminacją stało się ludobójstwo w 1915 roku i likwidacja półtora miliona Ormian żyjących w zachodniej Armenii.

Ci, którzy zdołali się ocalić, uciekli w różnych kierunkach. Część z nich przekroczyła granicę wschodniej Armenii, z której wkrótce Rosja wycofała się, podobnie jak z całego południowego Kaukazu po wybuchu wojny domowej. Powstała tam w 1918 roku krótkotrwała Republika Armenii, później przekształconą w republikę sowiecką. Inni uchodzili do sąsiednich krajów chrześcijańskich, takich jak Bułgaria czy Grecja, gdzie już istniała ormiańska diaspora. Większa liczba Ormian została przyjęta w nowo założonych państwach arabskich, głównie w Syrii i Libanie. Chociaż te ostatnie diaspory były dobrze zintegrowane z krajami przyjmującymi, nie uległy asymilacji, pozostały kulturalnie ormiańskie i nadal odgrywają ważną rolę w zachowaniu zachodniego ormiańskiego języka i kultury. W końcu niektórzy uciekinierzy przed ludobójstwem znaleźli schronienie w bardziej odległych krajach, głównie w obu Amerykach i we Francji, których gospodarka rozpaczliwie potrzebowała siły roboczej po ciężkich stratach pierwszej wojny światowej.

\section{Współczesne diaspory ormiańskie}

W 1991 roku Republika Armenii uzyskała niepodległość, ale wkrótce znalazła się w trudnych warunkach: wojna z Azerbejdżanem, problem Górskiego Karabachu, sytuacja gospodarcza, korupcja. W rezultacie wielu Ormian opuszcza ojczyznę. Jest to czysty przykład migracji zarobkowej, skierowanej głównie do Rosji i Stanów Zjednocznonych. Ci nowi są zasadniczo zaabsorbowani swoją sytuacją materialną, na ogół żyją między sobą, tworząc pewnego rodzaju getta, 
i prawie nie mieszają się z lokalnymi Ormianami. Ponadto mówią oni językiem wschodnioormiańskim, podczas gdy, z wyjątkiem Rosji i Persji, lokalni Ormianie są potomkami zachodnich Ormian.

Obecnie w Rosji mieszka około półtora miliona Ormian, z których część zgromadziła ogromne fortuny, a około miliona w Stanach Zjednocznonych, szczególnie w Kalifornii. Oprócz tych dwóch „gigantów” Gruzja nadal chroni historyczną diasporę, głównie w Tbilisi, a większość w Dżawachetii, regionie graniczącym z Armenią, gdzie Ormianie korzystają oficjalnie z niektórych praw narodowych, dotyczących np. języka i szkół. Inne główne ormiańskie diaspory istnieją we Francji, w Ameryce Łacińskiej, w Australii i na Bliskim Wschodzie (ilustr. T).

Które z nich można uznać za diaspory kulturowe? W wyniku wspólnotowej struktury w krajach muzułmańskich Liban - siedziba katolikosa, Konstantynopol - siedziba patriarchy, i Iran znajdują się w czołowce, jako jedyne cieszące się codzienną prasą ormiańską. W niektórych innych diasporach, takich jak Francja czy Argentyna, elita próbuje z mniejszym lub większym powodzeniem utrzymać życie kulturalne, ale kosztem olbrzymiego trudu, ponieważ asymilacja postępuje $\mathrm{z}$ pokolenia na pokolenie.

Tłumaczyła z języka angielskiego Nune Srapyan

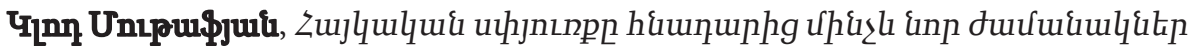

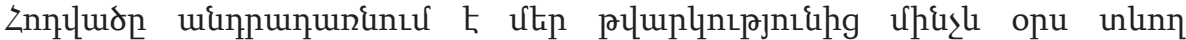

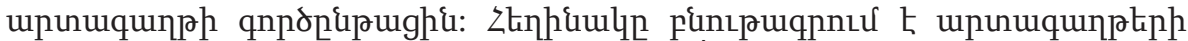

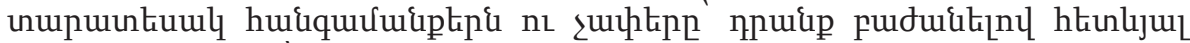

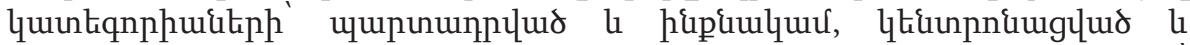

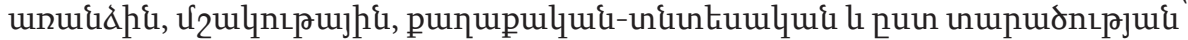

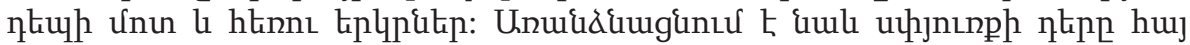

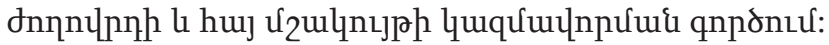

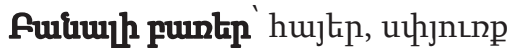

\section{Claude Mutafian, Armenian Diaspora from Antiquity to Modernity}

The article characterises the migration from Armenian territories which have been taking place since the start of our era until the $21^{\text {st }}$ century. It look into the size of diasporas and the circumstances surrounding their migration-related emergence. They are grouped into: distant and close, forced and voluntary, concentrated and scattered, cultural and political-economic. The value of diasporas for development of Armenian culture and nationality is highlighted.

Keywords: Armenians, diaspora 


$\begin{array}{llll}\text { Moguncja \# } & 1486 & \text { Padwa } & 1690 \\ \text { Wenecja } & 1511 & \text { Wiedeń } & 1731 \\ \text { Paryż \# } & 1538 & \text { Londyn } & 1736 \\ \text { Pawia \# } & 1539 & \text { Smyrna } & 1759 \\ \text { Zurych \# } & 1555 & \text { Eczmiadzyn } & 1772 \\ \text { Konstantynopol } & 1567 & \text { Madras } & 1772 \\ \text { Berlin \# } & 1574 & \text { Triest } & 1774 \\ \text { Rzym } & 1584 & \text { Petersburg } & 1781 \\ \text { Kolonia \# } & 1587 & \text { Nowy Nachiczewan } & 1790 \\ \text { Frankfurt \# } & 1593 & \text { Astrachań } & 1786 \\ \text { Lwów } & 1616 & \text { Kalkuta } & 1796 \\ \text { Mediolan } & 1621 & \text { Moskwa } & 1819 \\ \text { Paryż } & 1633 & \text { Bombaj } & 1820 \\ \text { Nowa Dżulfa } & 1638 & \text { Tyflis } & 1823 \\ \text { Livorno } & 1644 & \text { Szuszi } & 1828 \\ \text { Amsterdam } & 1660 & \text { Malta } & 1828 \\ \text { Jena } & 1665 & \text { Jerozolima } & 1833 \\ \text { Marsylia } & 1672 & \text { Jassy } & 1847 \\ \text { Lipsk } & 1680 & \text { Singapur } & 1847\end{array}$

A. Chronologia publikacji wydanych w języku ormiańskim (\# oznacza książki wydane częściowo po ormiańsku) 


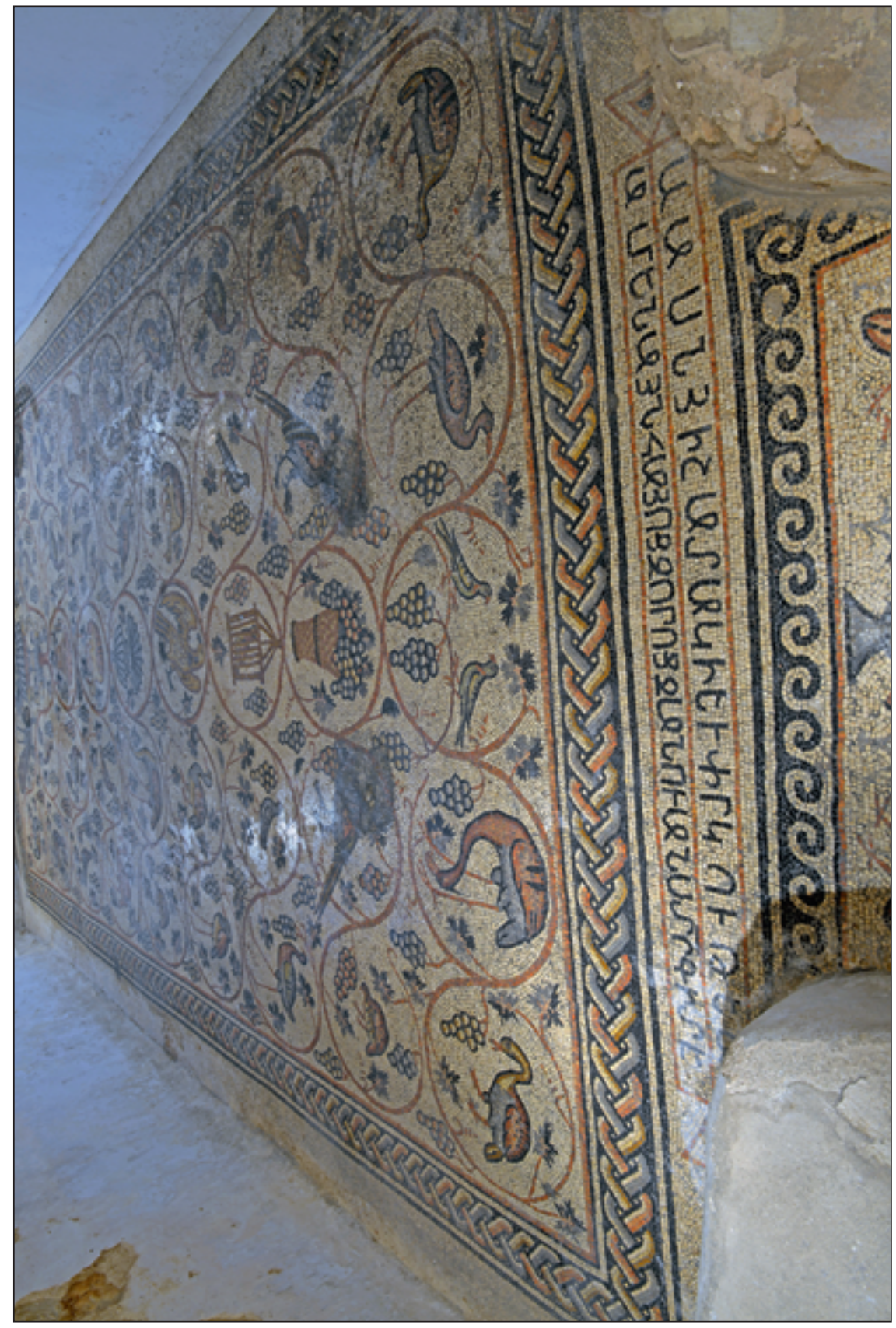

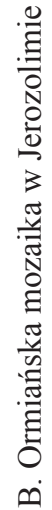




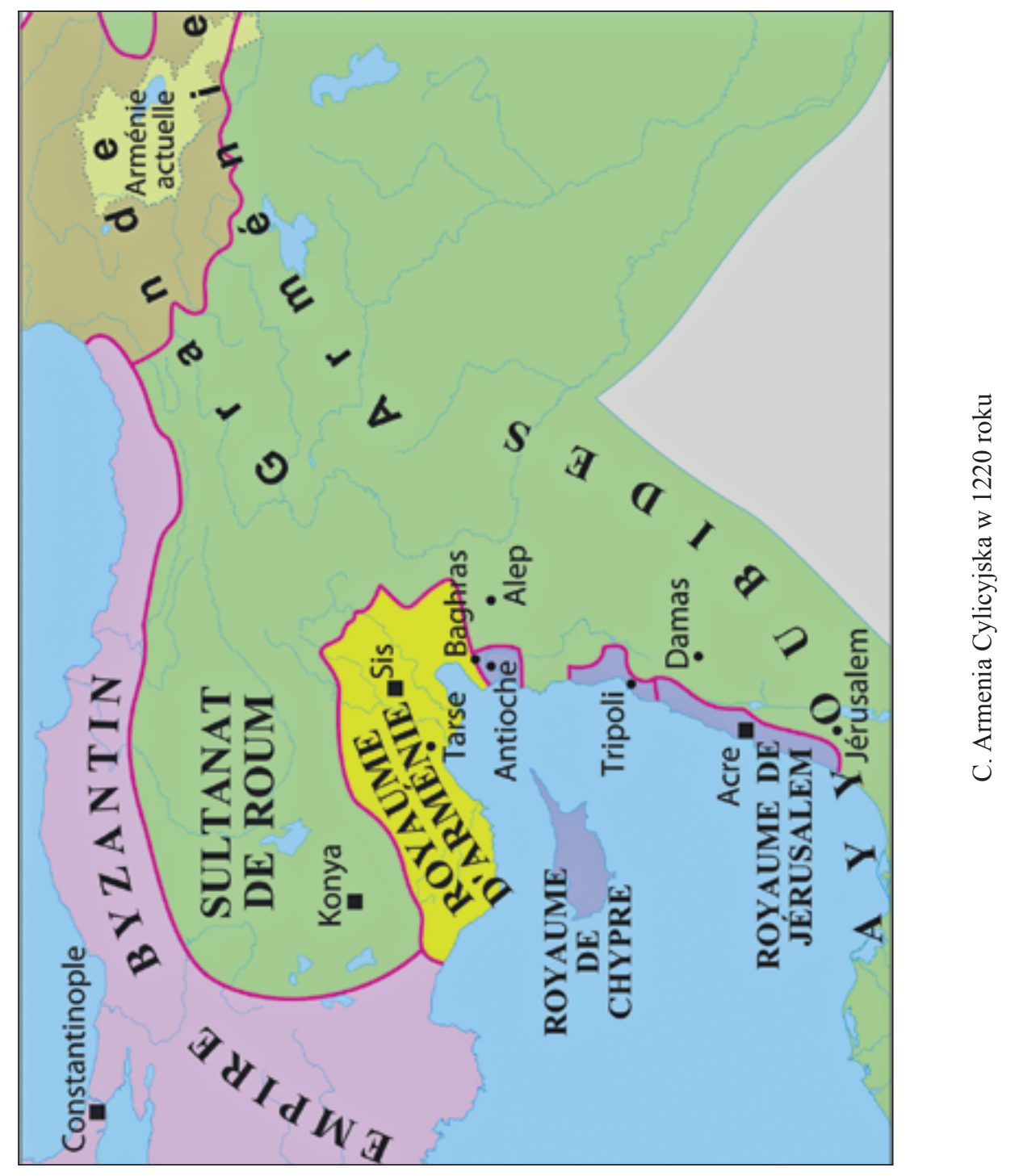




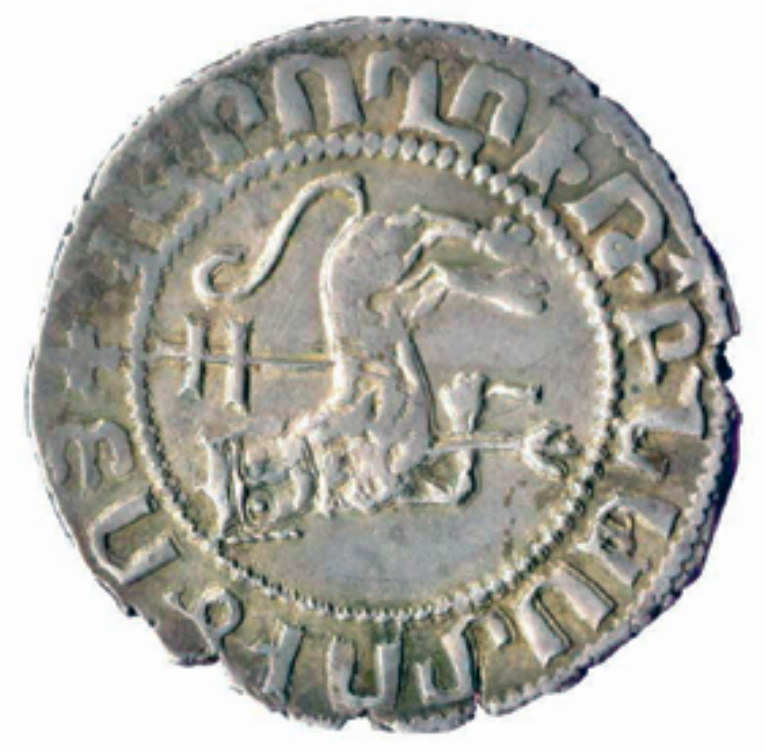

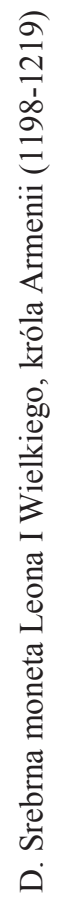

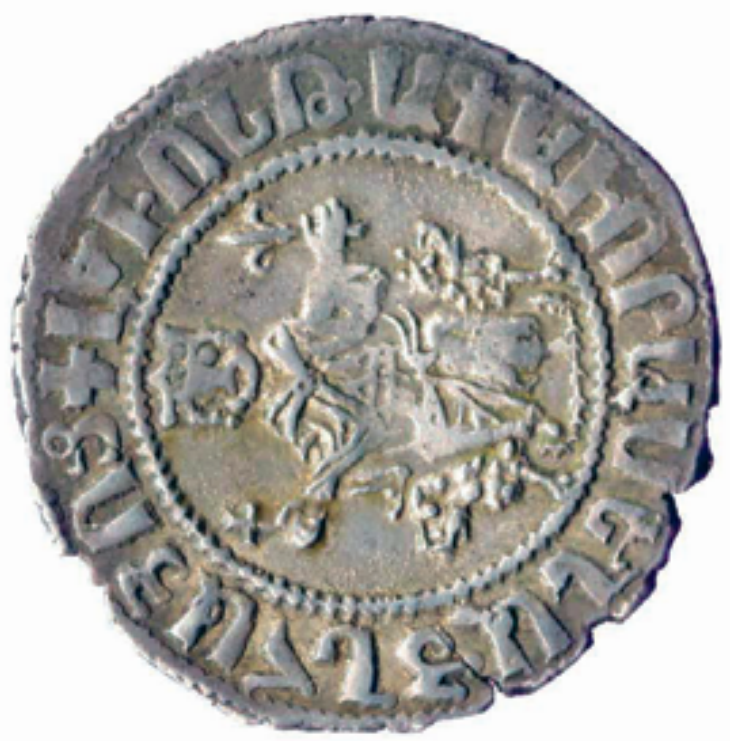




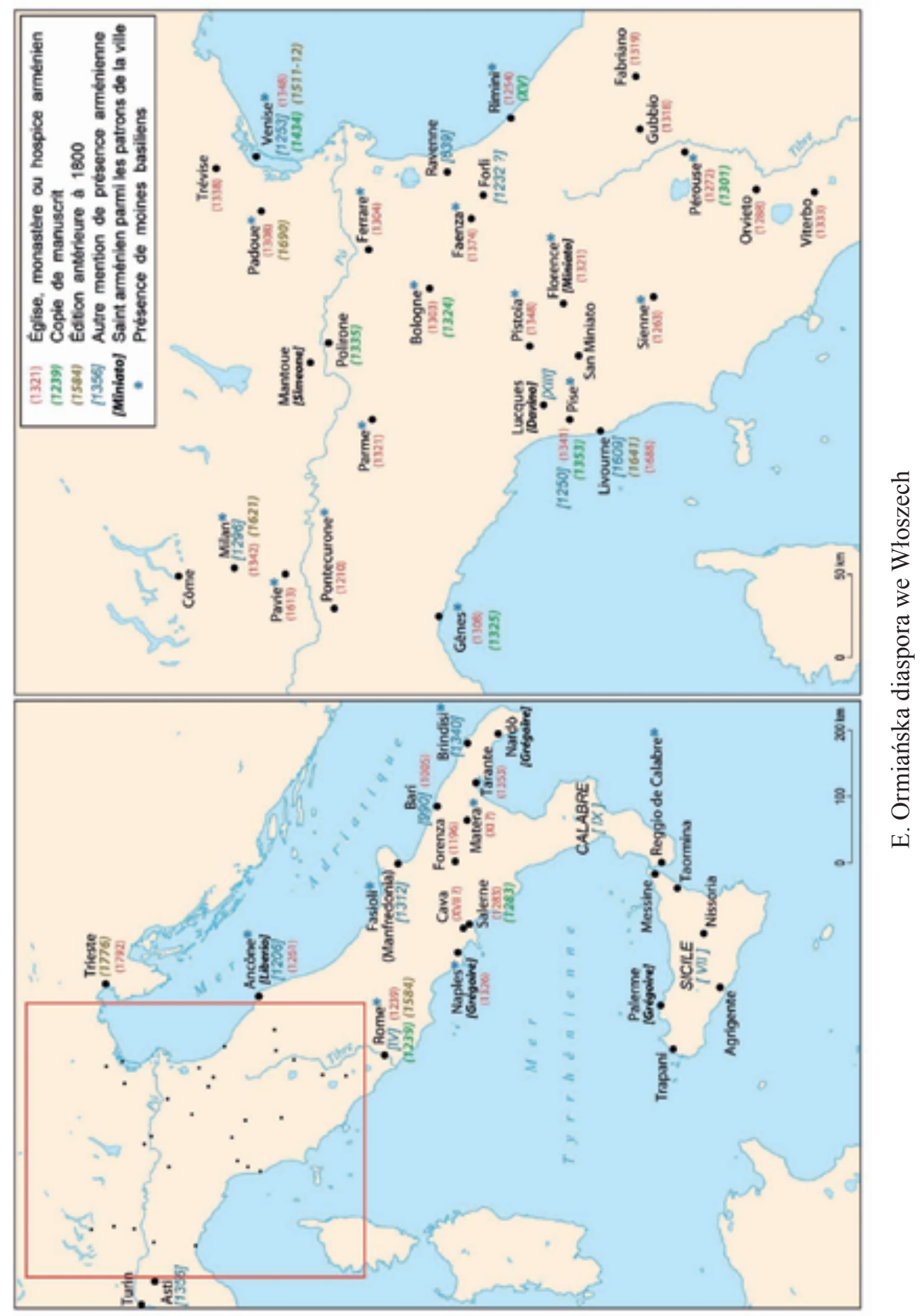




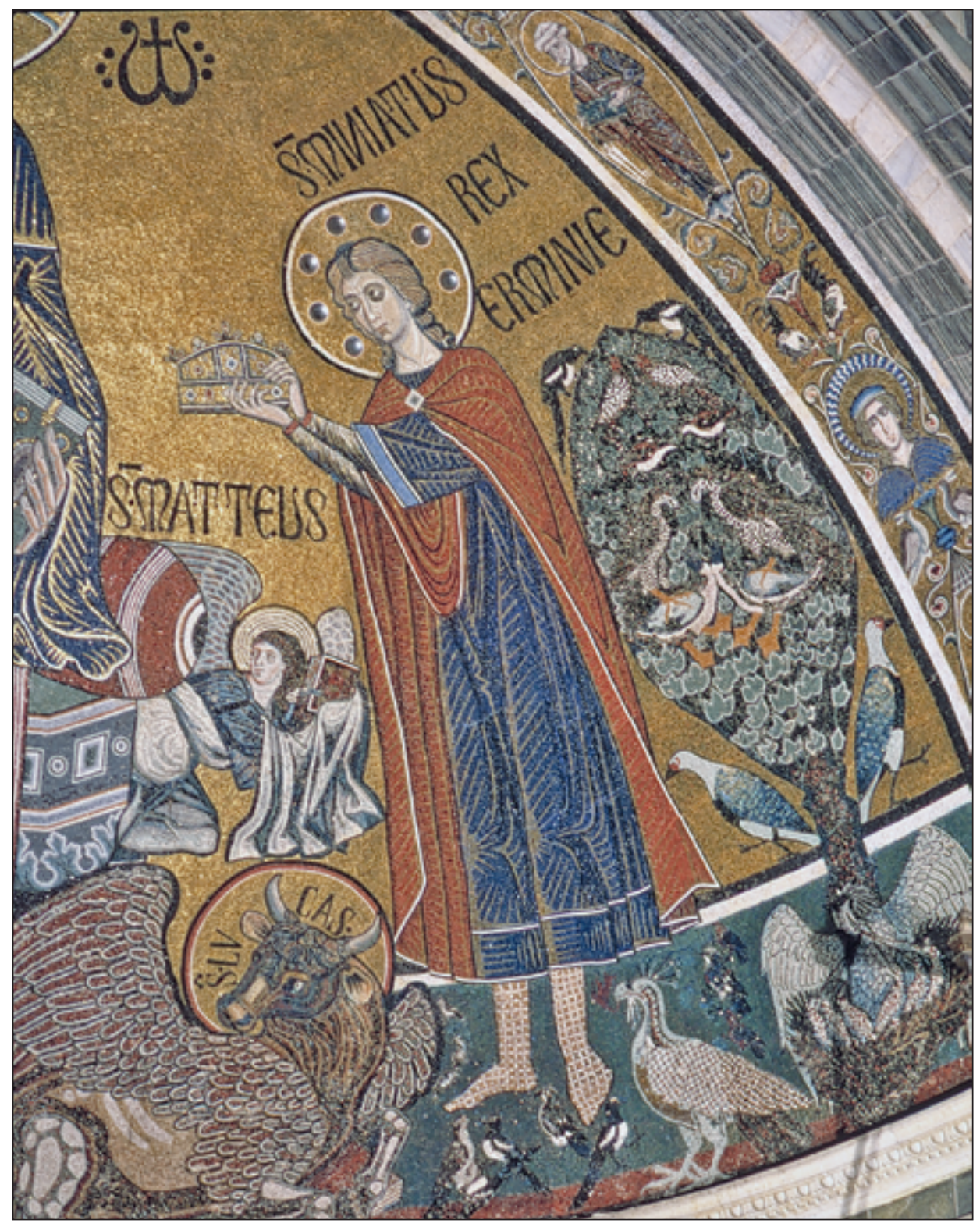

F. „S. Miniatus rex Erminie” - inskrypcja na mozaice absydy kościoła San Miniato al Monte we Florencji 


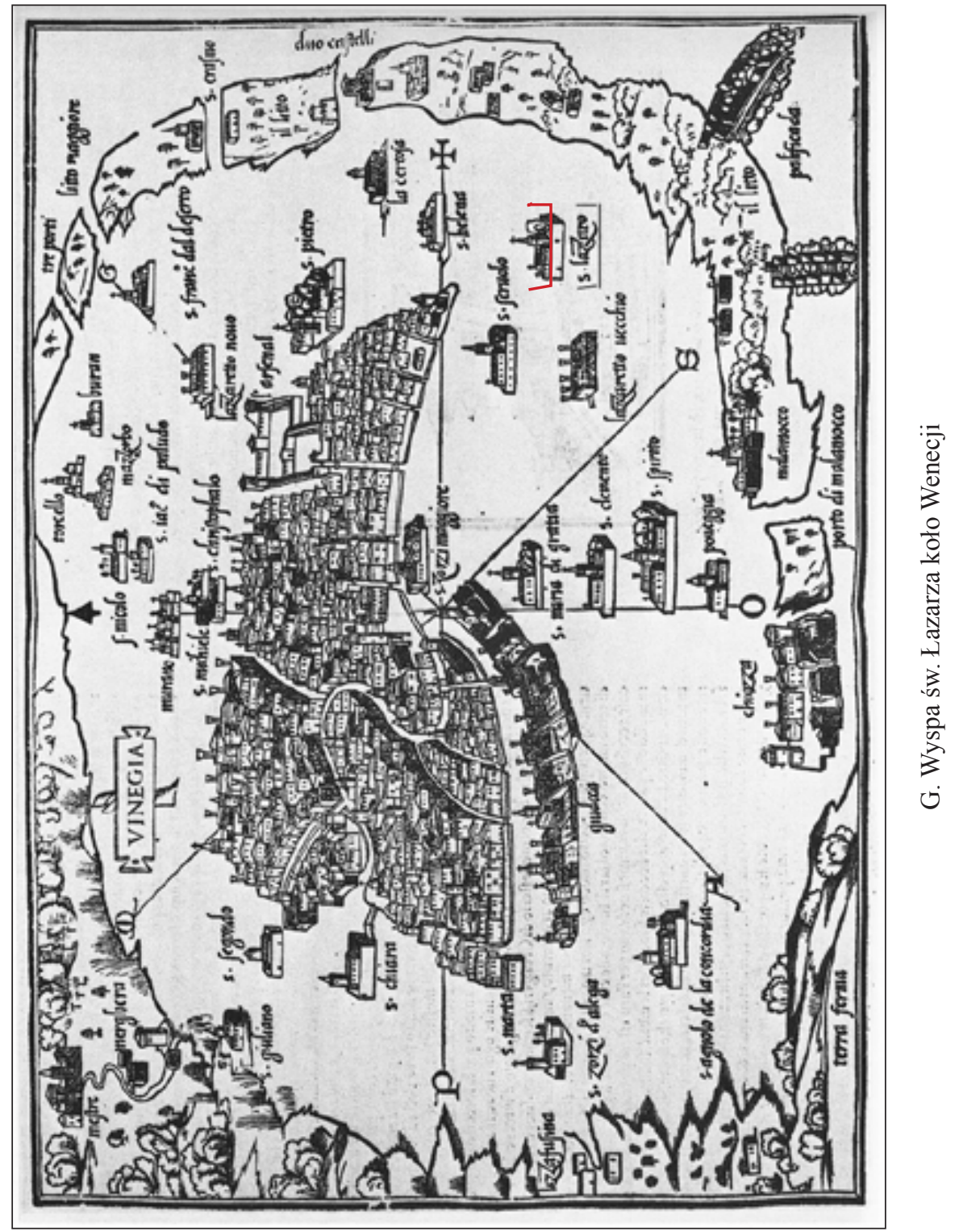




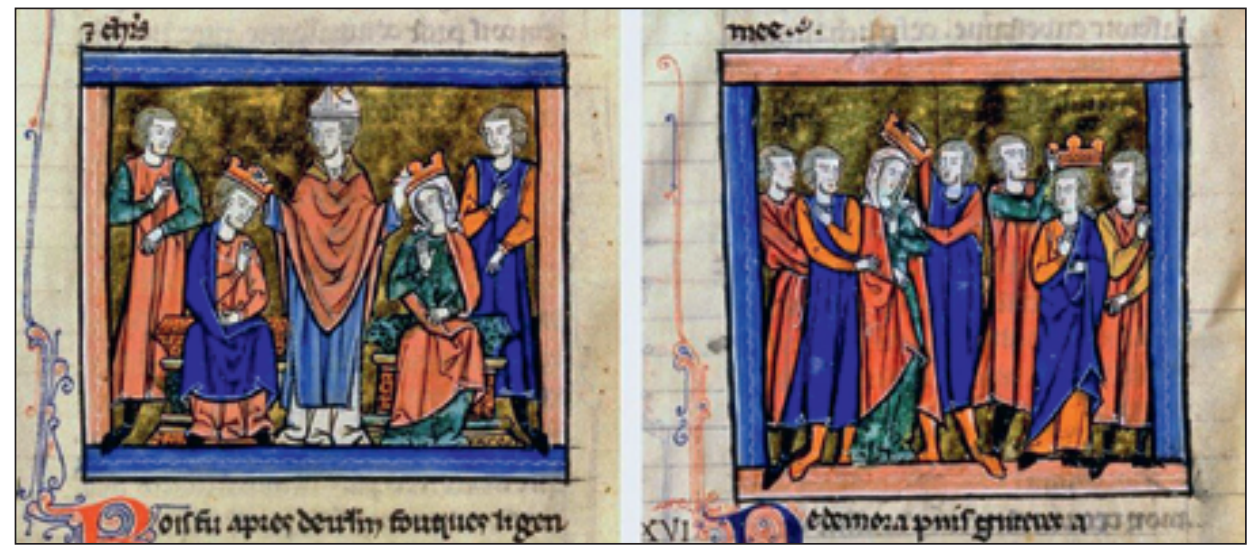

H. Melisanda, córka księżniczki ormiańskiej, trzecia królowa Jerozolimy, 1131-1161 (ms. fr. $779, \mathrm{BnF}, \mathrm{f}^{\text {os }} 123 \mathrm{v}, 145 \mathrm{v}$ )

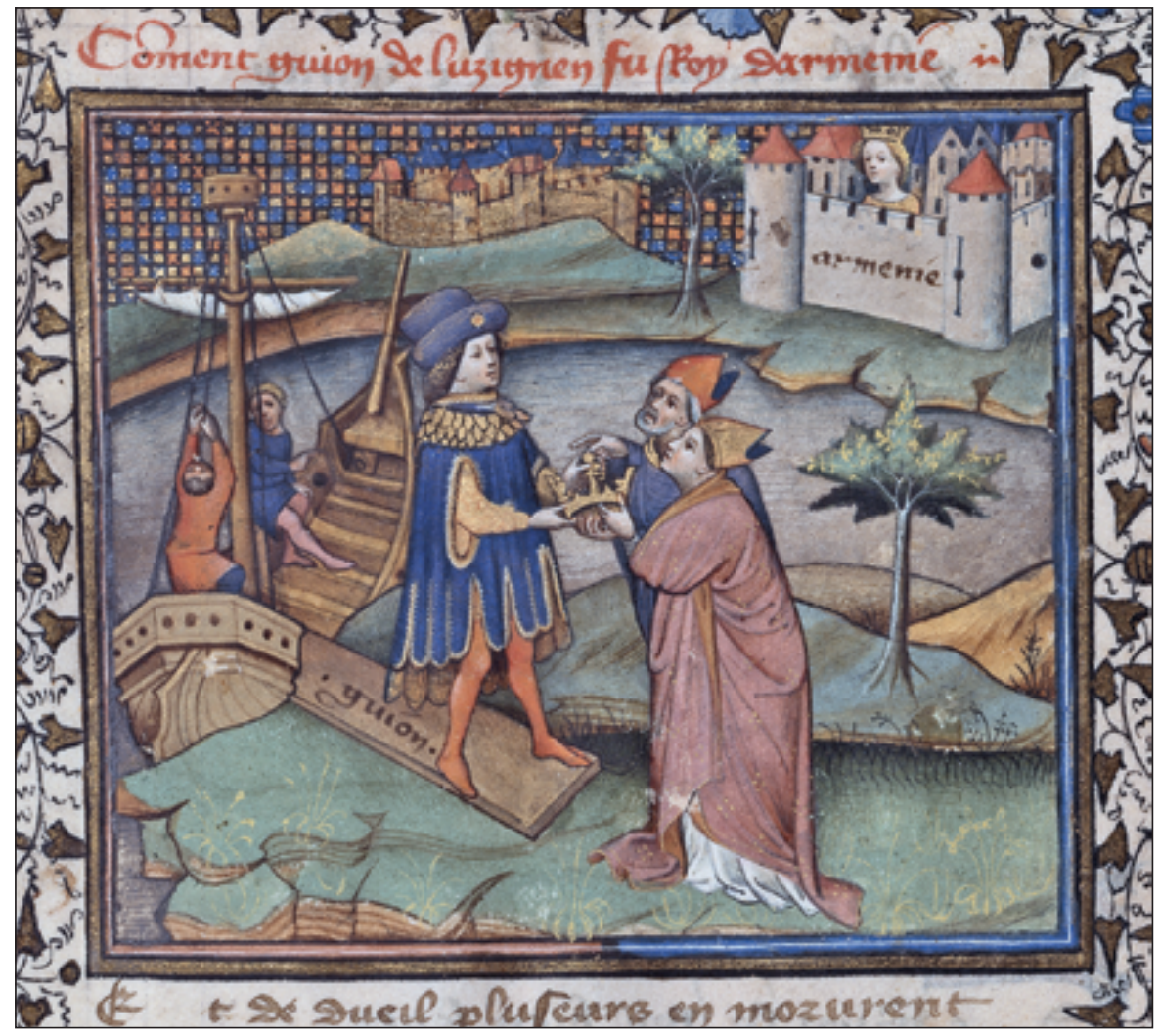

I. Rycerz Guy de Lusignan otrzymujący koronę Armenii w 1342 roku (ms. fr. 12575, BnF, fo $39 \mathrm{v}$ ) 


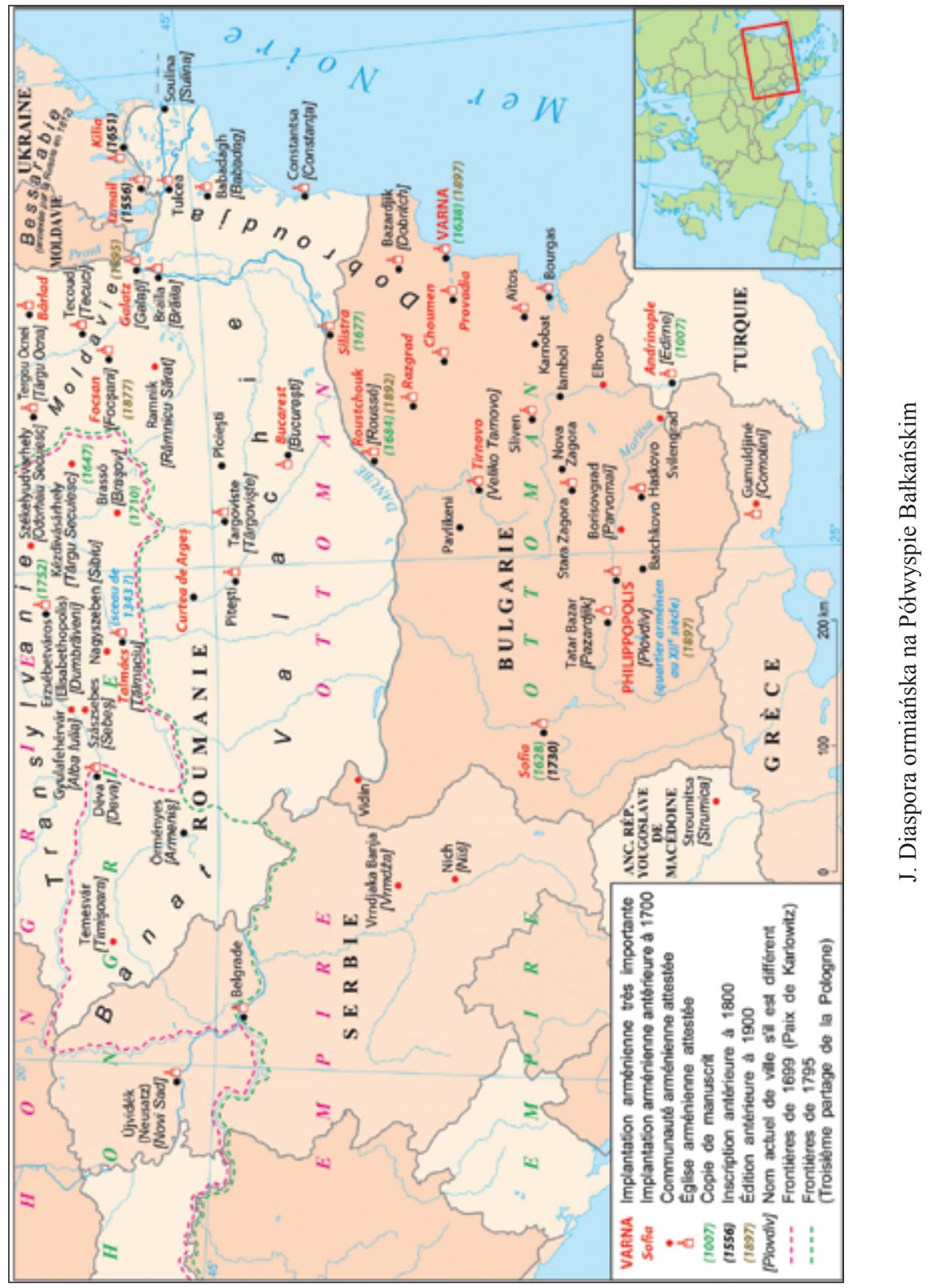




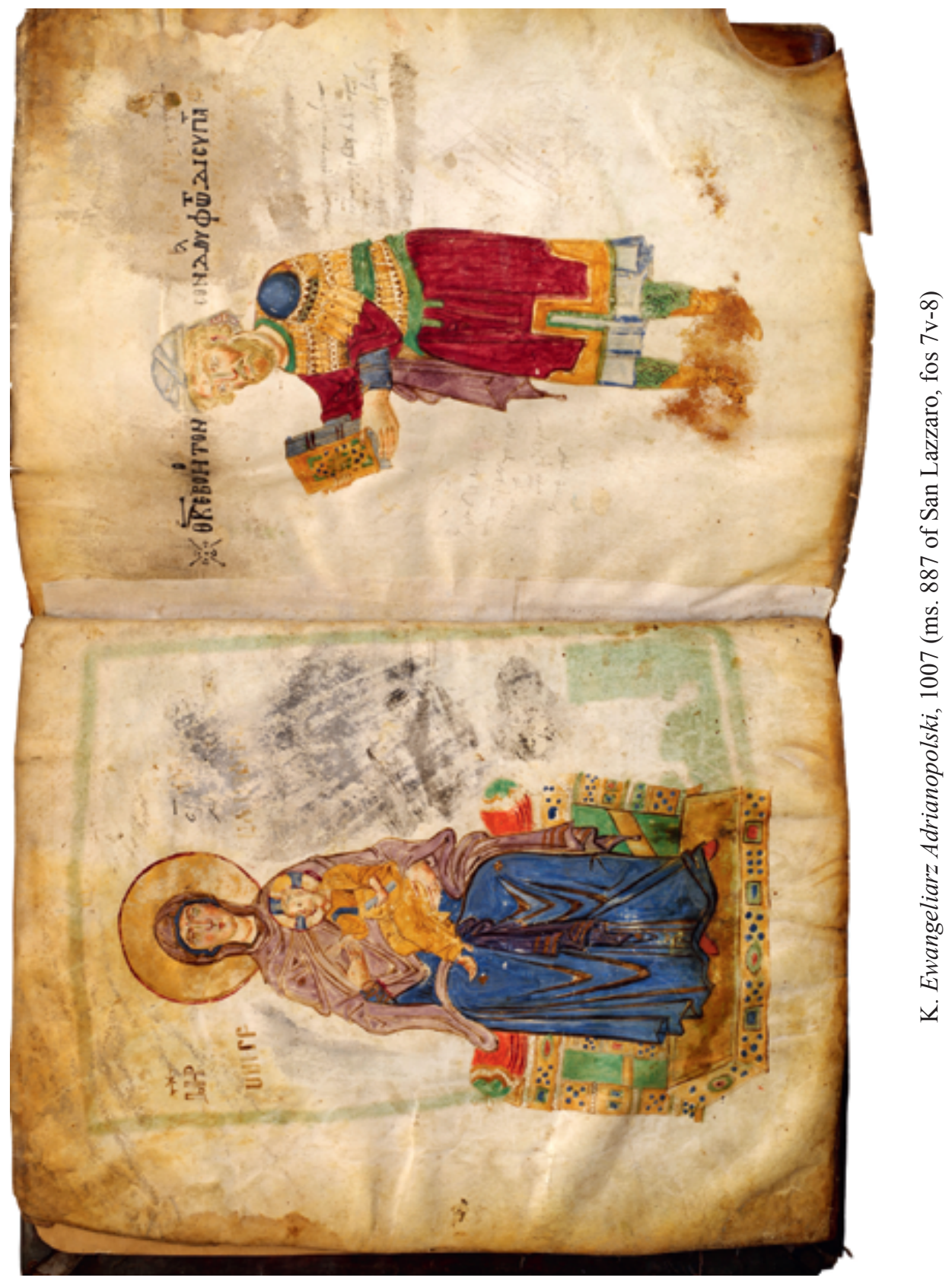




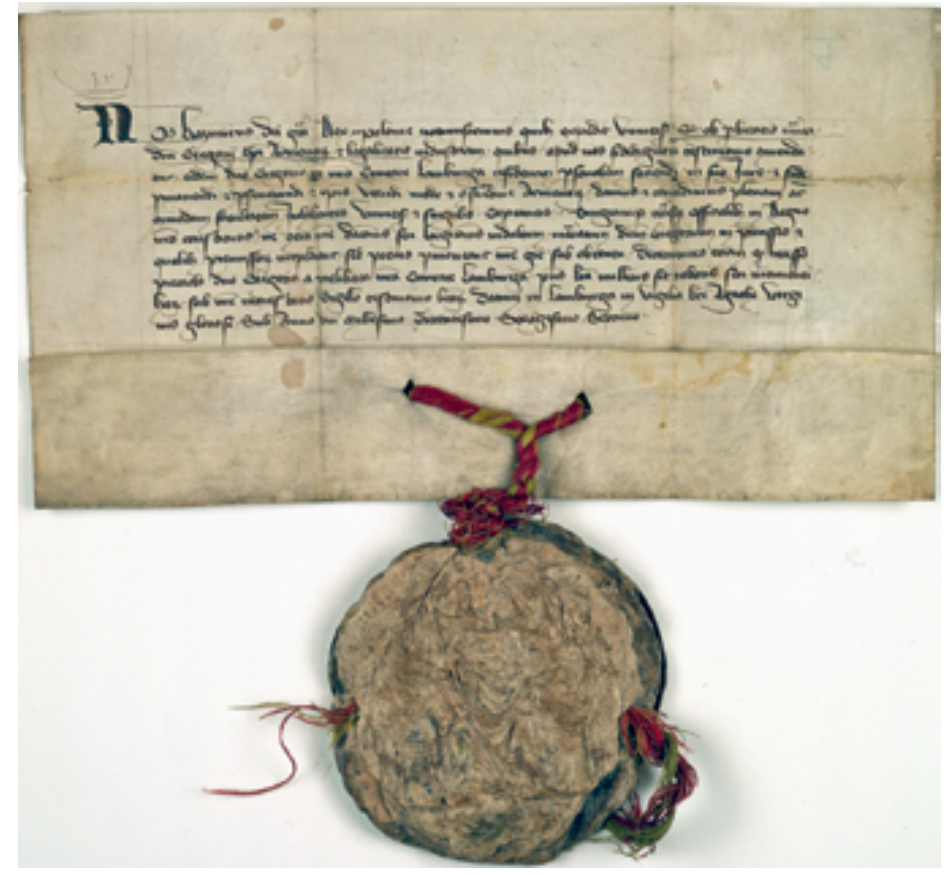

L. Dokument króla Polski Kazimierza Wielkiego z 1367 roku gwarantujący przywileje dla Ormian

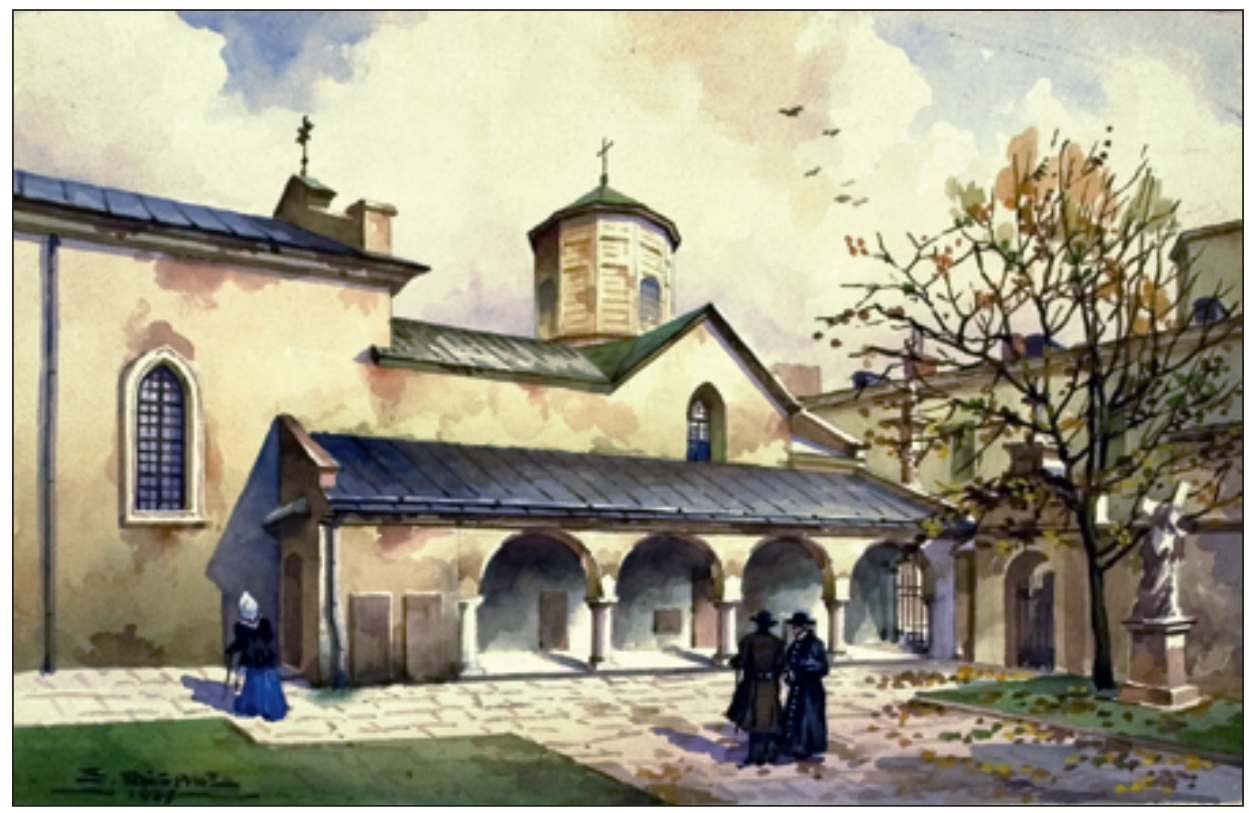

Ł. Katedra ormiańska we Lwowie, akwarela Stanisława Bisanza, 1937 


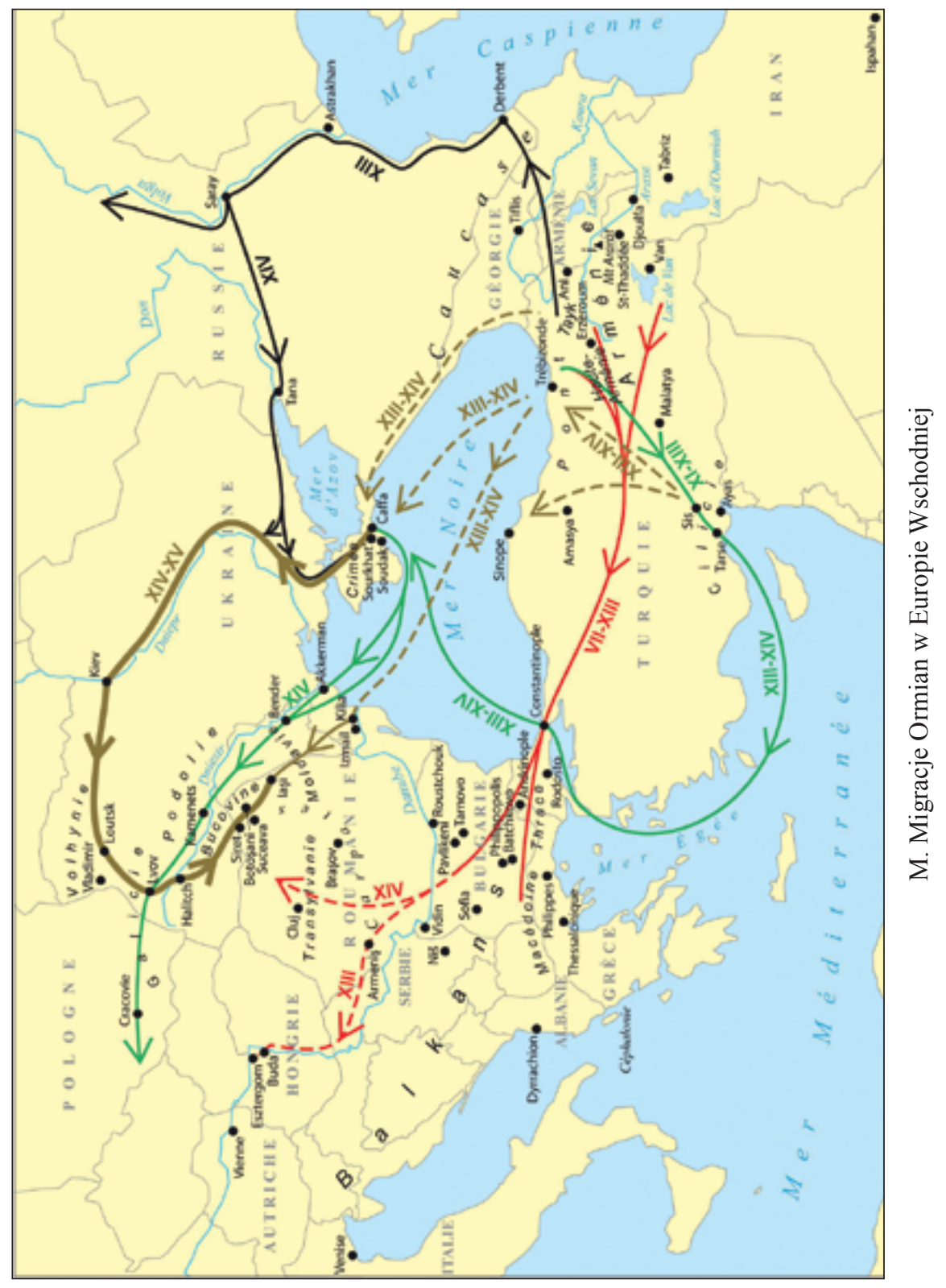




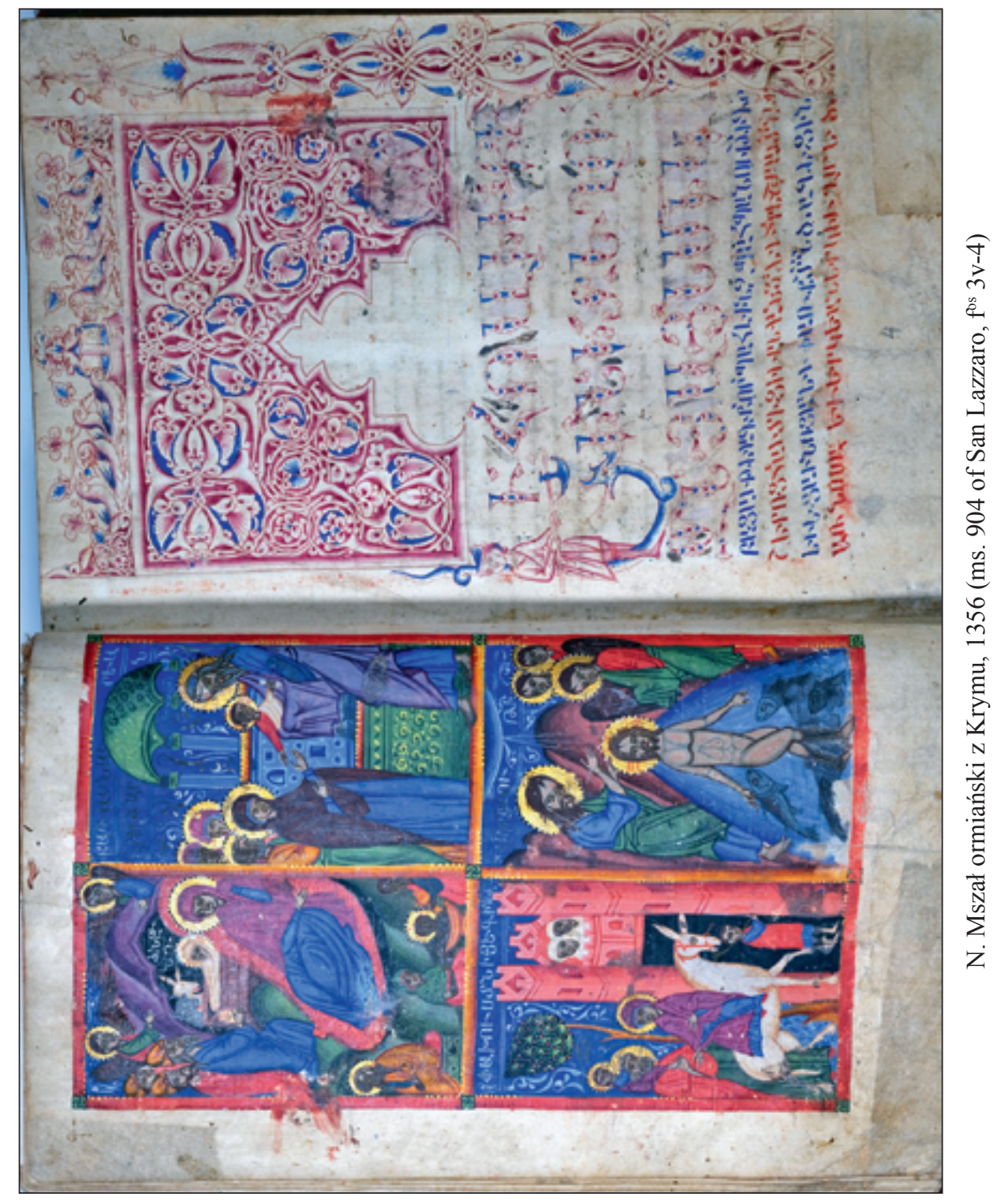




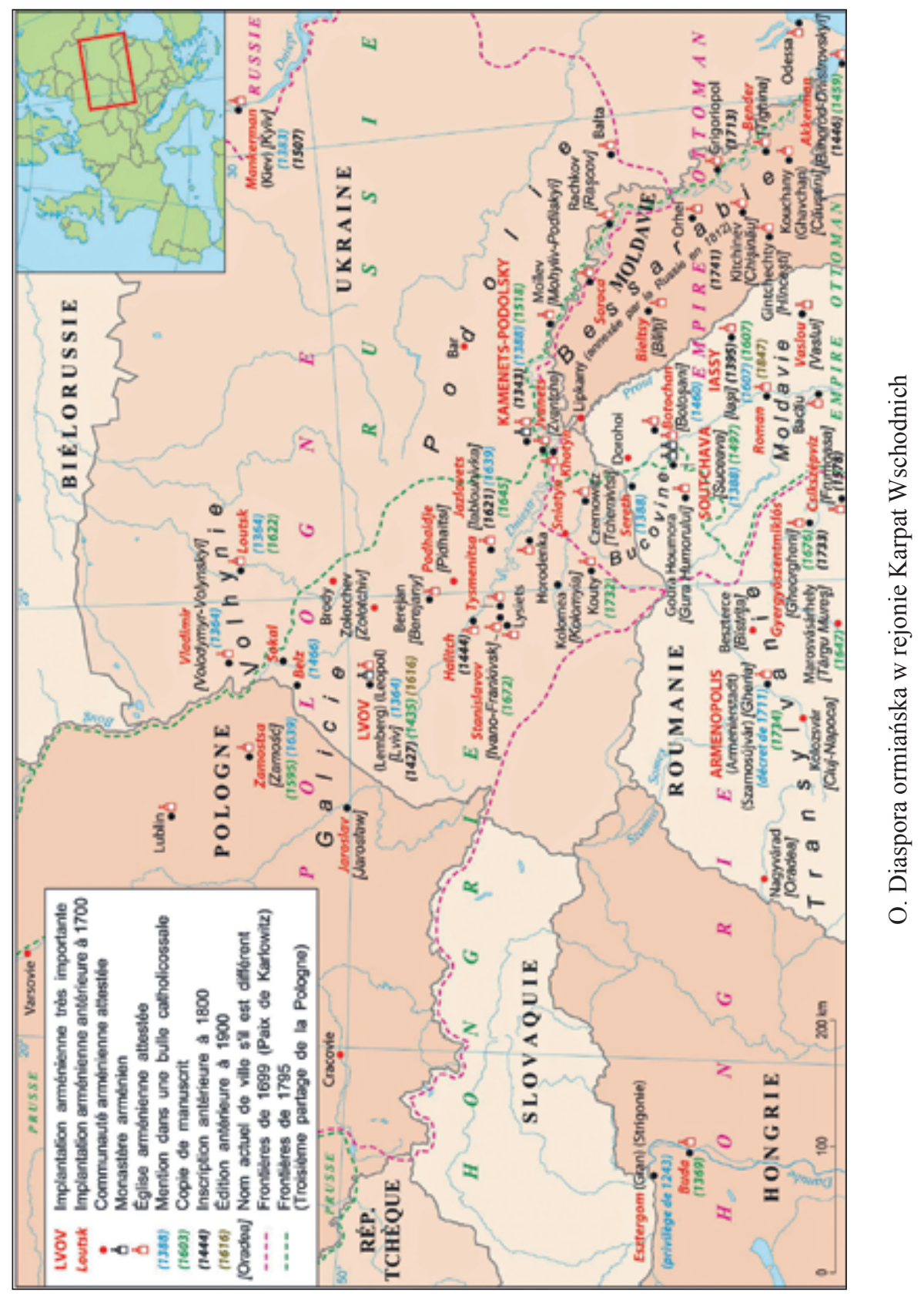




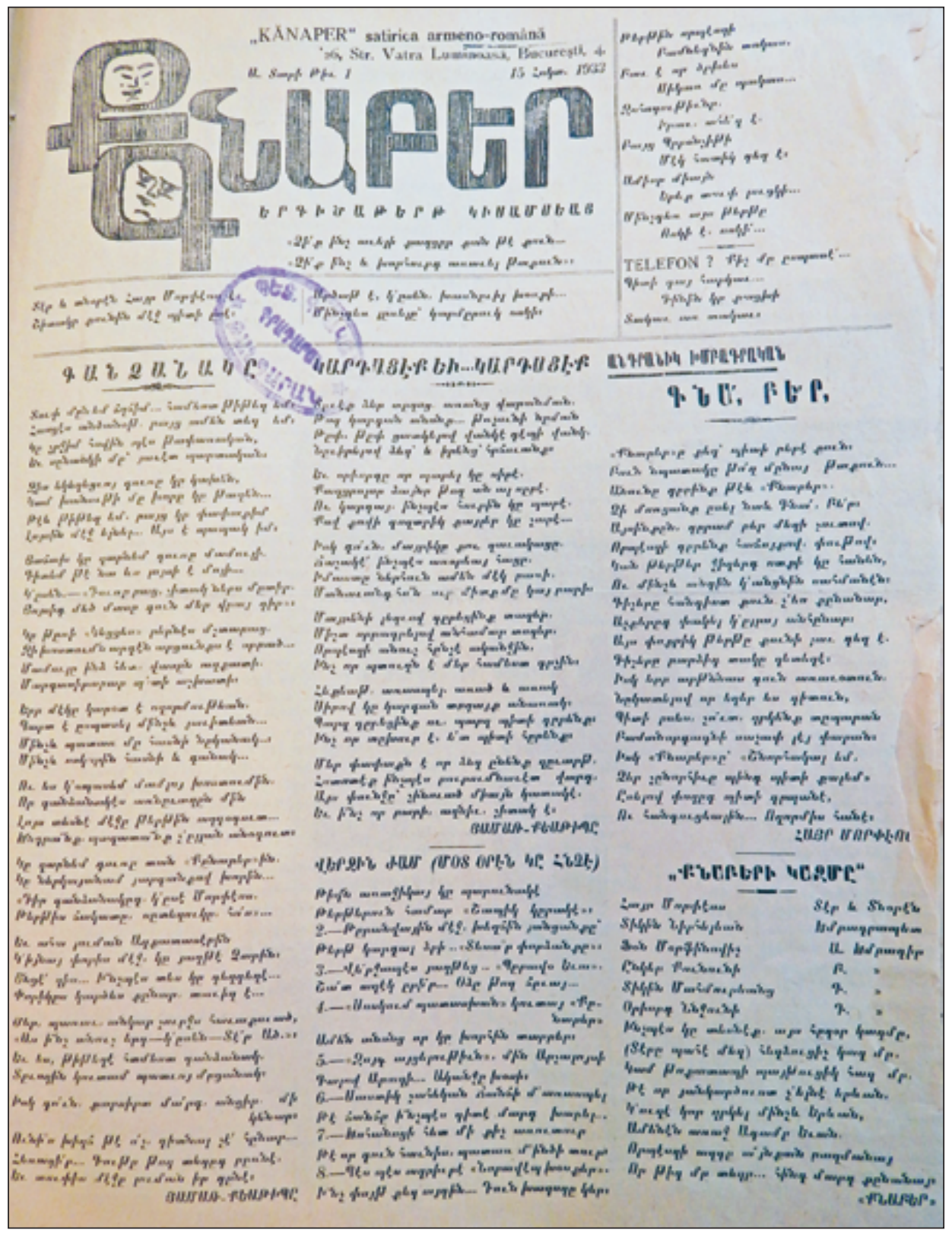

P. Ormiańskie czasopismo satyryczne z Rumunii, którego pierwszy numer ukazał się 15 października 1933 roku 


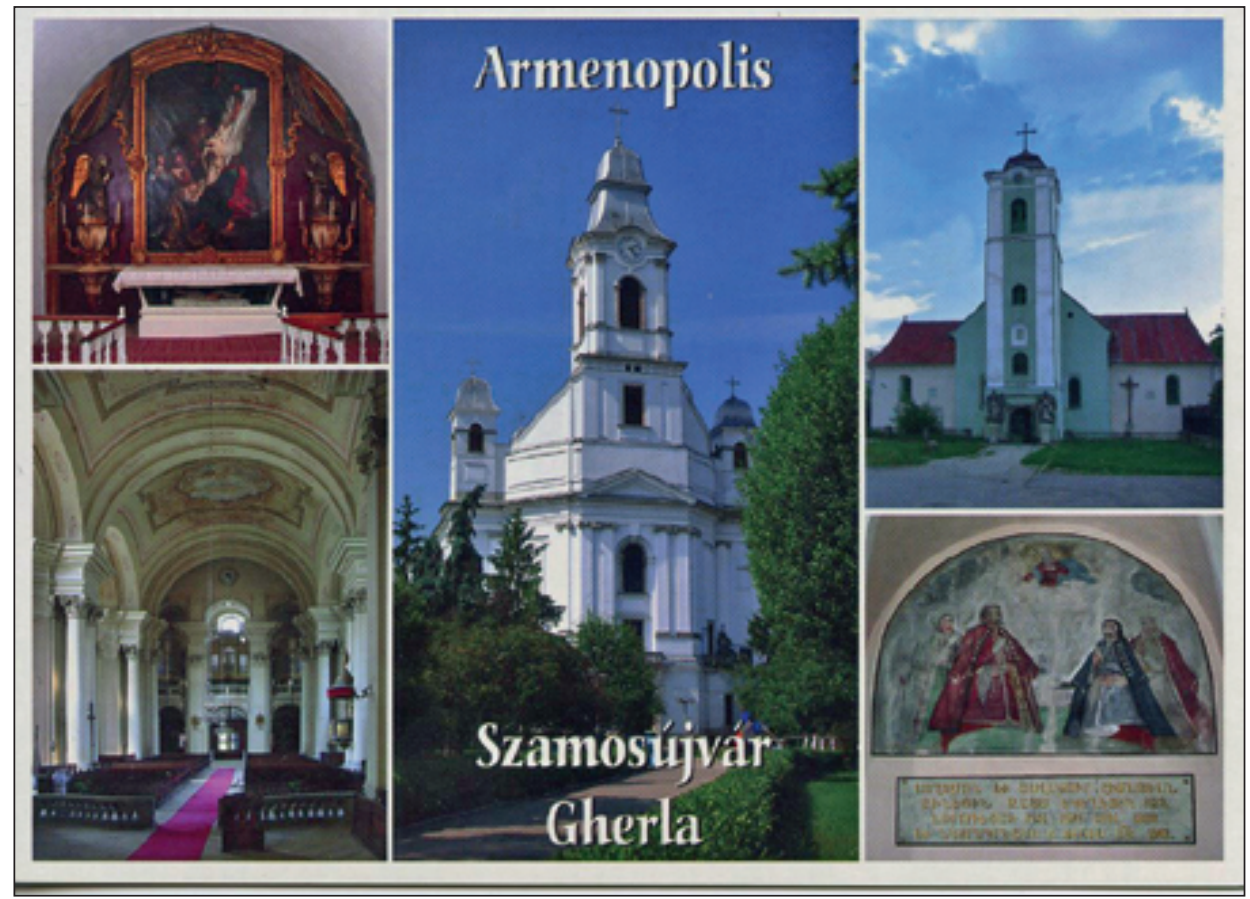

Q. Pocztówka z Armenopolis 


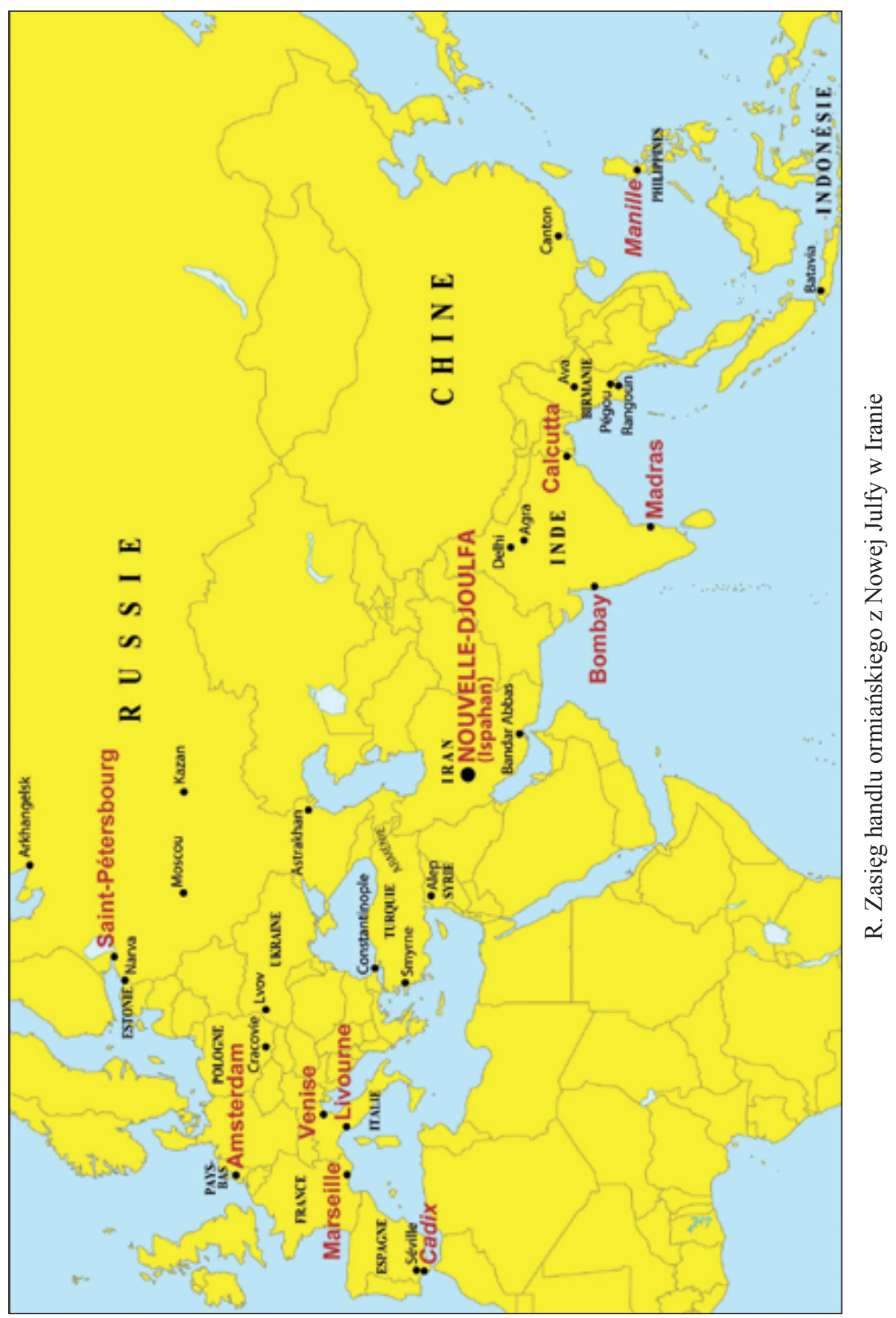




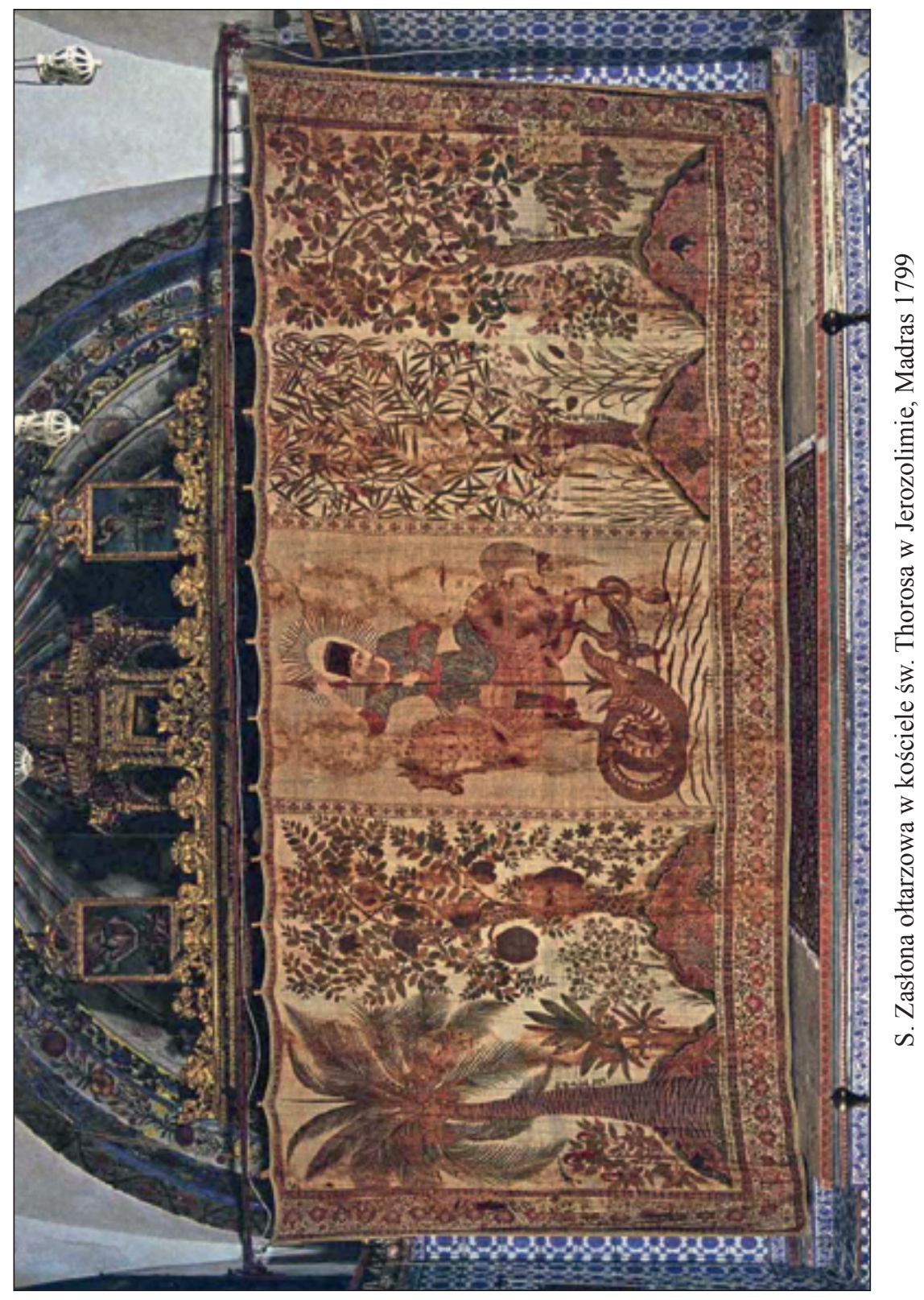




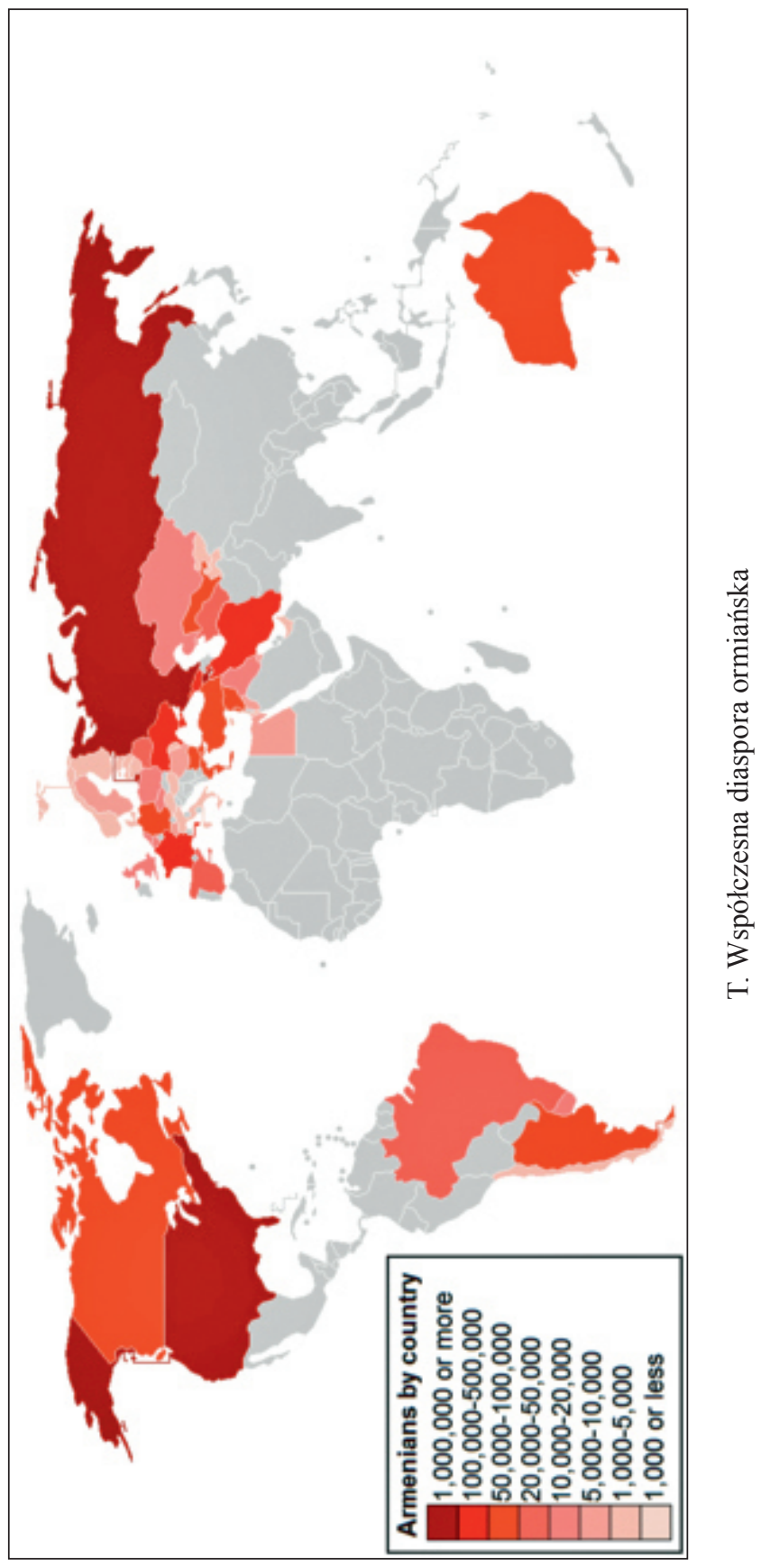

